\title{
Role of shallow electronic traps formed by oxygen vacancies in formation of luminescent properties of $\mathrm{CeO}_{2-x}$ nanocrystals
}

\author{
P.O.Maksimchuk, V.V.Seminko, I.I.Bespalova, A.A.Masalov \\ Institute for Scintillation Materials, STC "Institute for Single Crystals", \\ National Academy of Sciences of Ukraine, \\ 60 Lenin Ave., 61001 Kharkiv, Ukraine
}

Received March 3, 2014

\begin{abstract}
In the paper methods of thermoluminescence (TSL) and time-resolved spectroscopy were used for investigation of shallow electron traps near edge of $4 f^{0}$ band in $\mathrm{CeO}_{2}$ and nonstoichiometric $\mathrm{CeO}_{2-x}$ nanocrystals. It was shown that presence of the electronic traps located about $0.2 \mathrm{eV}$ lower than the bottom of $4 f^{0}$ band leads to sufficient modification of $\mathrm{O} 2 p-\mathrm{Ce} 4 f$ excitation relaxation processes due to excitation retrapping. Strong dependence of TSL signal on the stoichiometry of nanocrystal allows to suppose that electronic defects are associated with oxygen vacancies and are formed by $F^{+}$centers.
\end{abstract}

Методами термолюминесценции и время-разрешенной спектроскопии исследованы мелкие электронные ловушки вблизи края $4 f^{0}$ зоны в нанокристаллах $\mathrm{CeO}_{2}$ и $\mathrm{CeO}_{2-x}$. Показано, что наличие электронных ловушек, расположенных на 0,2 эВ ниже края $4 f^{0}$ зоны, приводит к существенному изменению процессов релаксации О2p-Ce4f возбуждения, что обусловлено высокой вероятностью перезахвата возбуждения. Существенная зависимость сигнала термолюминесценции от стехиометрии нанокристалла позволяет предположить, что электронные дефекты связаны с кислородными вакансиями и, вероятнее всего, образованы $F^{+}$-центрами.

Роль неглибоких електронних пасток, сформованих кисневими вакансіями, у формуванні люмінесцентних властивостей нанокристалів $\mathrm{CeO}_{2-x}$. П.О.Максилчук, В.В.Селінько, I.І.Беспалова, А.О.Масалов.

Методами термолюмінесценції та розподіленої у часі спектроскопії досліджено неглибокі електронні пастки поблизу краю $4 f^{0}$ зони у нанокристалах $\mathrm{CeO}_{2}$ i $\mathrm{CeO}_{2-x}$. Показано, що наявність електронних пасток, розташованих на 0,2 еВ нижче краю $4 f^{0}$ зони, призводить до істотної зміни процесів релаксації О2p-Cе4f збудження, що зумовлено високою ймовірністю перезахоплення збудження. Істотна залежність сигналу термолюмінесценції від стехіометрії нанокристала дозволяє припустити, що електронні дефекти пов'язані з кисневими вакансіями i, найімовірніше, утворені $F^{+}$-центрами.

\section{Introduction}

Cerium oxide $\left(\mathrm{CeO}_{2}\right)$ recently has attracted much attention as a material that can be effectively applied for catalysis [1], fuel cells [2,3] and oxygen sensors [4] due to its high oxygen sensitivity and oxygen storage capacity provided by facile $\mathrm{Ce}^{4+} / \mathrm{Ce}^{3+}$ redox cycles. As was shown in $[5$,
6], reversible $\mathrm{Ce}^{4+} \leftrightarrow \mathrm{Ce}^{3+}$ reduction/oxidation processes are facilitated for $\mathrm{CeO}_{2}$ nanocrystals as compared to correspondent bulk materials that is determined by the high degree of non-stoichiometry of ceria nanoparticles.

Cerium dioxide has the luorite structure with FCC cubic lattice, which consists of a simple cubic oxygen sub-lattice with cerium 
ions occupying alternate cube centers $[7,8]$. Formation of range of non-stoichiometric $\mathrm{CeO}_{2-x}$ oxides (with $x=0 . \ldots 0.4$ ) was also observed. Non-stoichiometry of $\mathrm{CeO}_{2-x}$ is determined by oxygen vacancies in the lattice. In spite of the high concentration of vacancies the fluorite-type structure is preserved for the all range of oxides while the part of $\mathrm{Ce}^{4+}$ ions is reduced to $\mathrm{Ce}^{3+}$ ones [9].

Luminescent properties of $\mathrm{CeO}_{2}$ nanocrystals were investigated in the number of papers recently [10-12]. As was shown, luminescence of ceria is connected strongly with stoichiometry of nanocrystals and is determined by different $F$-centers $\left(F^{0}, F^{+}\right.$and $\left.F^{2+}\right)$ [11], subsurface defects [10] and $\mathrm{Ce}^{3+}$ ions (for non-stoichiometric ceria nanocrystals) [12]. In our recent paper [12] Ce4f-O2p charge transfer (CT) luminescence of both stoichiometric and nonstoichiometric $\mathrm{CeO}_{2}$ nanocrystals was observed as well. Dependence of luminescence characteristics of ceria on the method of synthesis, treatment atmosphere and size of nanocrystals complicates sufficiently the assignment of the bands observed in the spectrum to the peculiar centers.

As was shown both theoretically [13] and experimentally [11] oxygen vacancy in $\mathrm{CeO}_{2}$ can capture an electron (or two electrons) remained after oxygen release thus forming $F^{+}$or $F^{0}$ centers. Position of electronic levels of all $F$ centers are close to the bottom of empty $4 f^{0}$ band so one can suppose that these centers can act also as electronic traps for electrons from $4 f^{0}$ band. So the sufficient influence of concentration of oxygen vacancies on the relaxation processes of O2p-Ce4f excitations, and, correspondingly, on the luminescence properties of ceria nanocrystals can be expected.

In this paper we have used the methods of thermoluminescence to determine whether the electronic traps are present in sol-gel obtained $\mathrm{CeO}_{2}$ nanocrystals; their nature, depth and dependence on the stoichiometry of nanocrystal were determined as well. Also the influence of shallow electron traps on the processes of charge transfer excitation relaxation was shown.

\section{Methods and materials}

$\mathrm{CeO}_{2}$ nanocrystals were obtained by Pechini method [14]. Cerium oxide $\mathrm{CeO}_{2}$ $(99.999 \%$, Sigma-Aldrich) was dissolved in the mixture of nitric acid $\mathrm{HNO}_{3}$ and hydrogen peroxide $\mathrm{H}_{2} \mathrm{O}_{2}$ (in $1: 1$ volume ratio). The solution of $0.75 \mathrm{~g}$ of citric acid and $1 \mathrm{ml}$ of ethylene glycol was added to $20 \mathrm{ml}$ of cerium nitrate $\mathrm{Ce}\left(\mathrm{NO}_{3}\right)_{3}(c=1 \mathrm{~mol} / \mathrm{l})$ solution. The resulting mixture was treated at $80^{\circ} \mathrm{C}$ during $10 \mathrm{~h}$ and then hydrolyzed by means of 10 mass. $\% \mathrm{NH}_{3}$ water solution. The precipitate was dried at $120^{\circ} \mathrm{C}$ during $5 \mathrm{~h}$ and then dehydrated at $250^{\circ} \mathrm{C}$ during $4 \mathrm{~h}$. Stoichiometry of the nanocrystal depend on the atmosphere in which high-temperature treatment is carried out. Reducing atmosphere stimulates the formation of oxygen vacancies and, consequently, the formation of nonstoichiometric oxides. In the oxidizing atmosphere number of oxygen vacancies in the crystal is much lower thus leading to formation of $\mathrm{CeO}_{2}$ crystalline phase. To obtain a different degree of stoichiometry, nanocrystals were annealed during $2 \mathrm{~h}$ in different atmospheres - oxidizing (air) and reducing (hydrogen) at $900^{\circ} \mathrm{C}$.

Luminescence spectra were obtained using spectrofluorimeter based on the grating monochromator, luminescence was excited by $\mathrm{He}-\mathrm{Cd}$ laser with $\lambda_{\text {exc }}=325 \mathrm{~nm}$. Decay curves were measured by the method of time-correlated single photon counting using FluoTime200 picosecond spectrofluorimeter (PicoQuant, Germany). Investigations were carried out at $293 \mathrm{~K}$ and $77 \mathrm{~K}$. The thermoluminescence glow curves were obtained by linear heating from 50 to $290 \mathrm{~K}$ at the heating rate of $2 \mathrm{~K} / \mathrm{s}$ after irradiation with $\mathrm{He}-\mathrm{Cd}$ laser $\left(\lambda_{\text {exc }}=\right.$ $325 \mathrm{~nm}$ ) for $15 \mathrm{~min}$. The radiation of samples was detected by R9110 Hamamatsu photomultiplier tube.

X-ray diffraction patterns of obtained stoichiometric and nonstoichiometric $\mathrm{CeO}_{2}$ nanocrystals are shown in the Fig. 1. All the diffraction peaks in these patterns can be indexed to a fluorite cubic phase of $\mathrm{CeO}_{2}$ (JCPDS 34-0394) (Fig. 1). There are diffraction angles of $28,33,47,56,59,69$ and 76 , which are corresponding to ceria $\left(\begin{array}{lll}1 & 1 & 1\end{array}\right)$, ( $\left.\begin{array}{lll}2 & 0 & 0\end{array}\right),\left(\begin{array}{lll}2 & 2 & 0\end{array}\right),\left(\begin{array}{lll}3 & 1 & 1\end{array}\right),\left(\begin{array}{lll}2 & 2 & 2\end{array}\right),\left(\begin{array}{lll}4 & 0 & 0\end{array}\right)$ and (3 31 1), respectively. So the structures of the samples are characterized by FCC fluorite-type lattice and formation of any additional phases at these conditions can be excluded.

The average size of nanocrystals was about $50 \mathrm{~nm}$ that was confirmed by TEM data (Fig. 2).

\section{Results and discussion}

Ceria is wide band gap $(\sim 6 \mathrm{eV})$ material with valence band formed by $\mathrm{O} 2 p$ and conduction band by Ce5d states. In the band gap of stoichiometric $\mathrm{CeO}_{2}$ narrow sub-band 


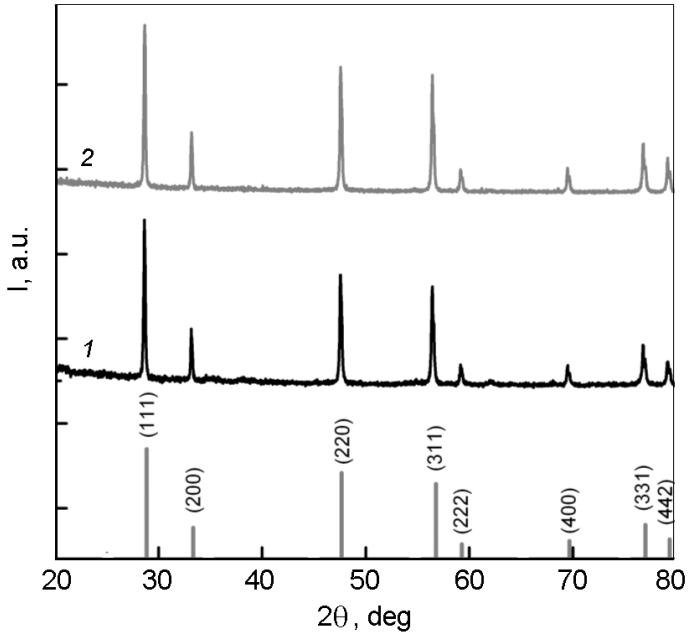

Fig. 1. XRD patterns of $\mathrm{CeO}_{2}$ nanocrystals ( $1-\mathrm{CeO}_{2}$ treated in oxidizing atmosphere; $2-\mathrm{CeO}_{2}$ treated in reducing atmosphere).

is present formed by empty $4 f^{0}$ states of $\mathrm{Ce}^{4+}$ ion. For non-stoichiometric $\mathrm{CeO}_{2-x}$ splitting of this band to the empty $4 f^{0}$ and filled $4 f^{1}$ sub-bands occurs. $\mathrm{Ce}^{4+} \rightarrow \mathrm{Ce}^{3+}$ transition providing filling of $4 f^{1}$ state can occur as via formation of oxygen vacancy and subsequent capture of excess electron by $\mathrm{Ce}^{4+}$ ion, so by charge transfer from oxygen ion at $\mathrm{O} 2 p \rightarrow \mathrm{Ce} 4 f$ excitation. As was shown in [12] both charge transfer ( $\mathrm{Ce}^{3+}+$ hole) and vacancy-stabilized ( $\mathrm{Ce}^{3+}+$ vacancy) states form separate luminescent centers which ratio can be controlled by atmosphere of treatment.

Spectra of $\mathrm{CeO}_{2}$ nanocrystals treated in oxidizing atmosphere (1) and reducing atmosphere (2) at $77 \mathrm{~K}$ are shown in the

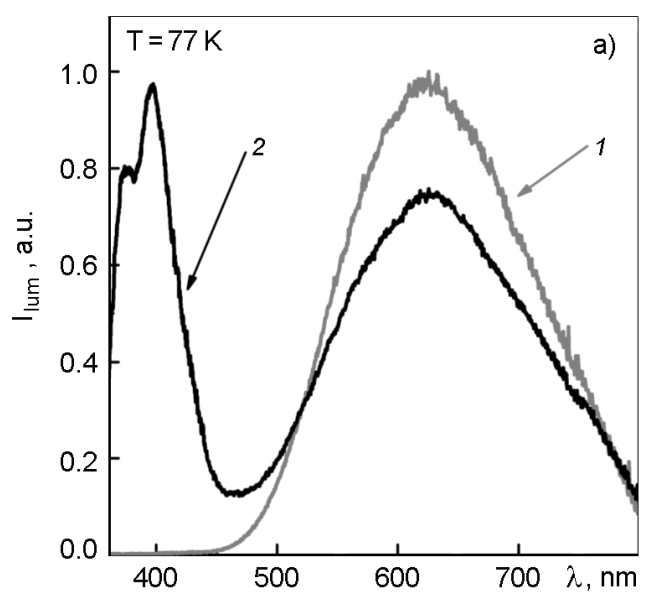

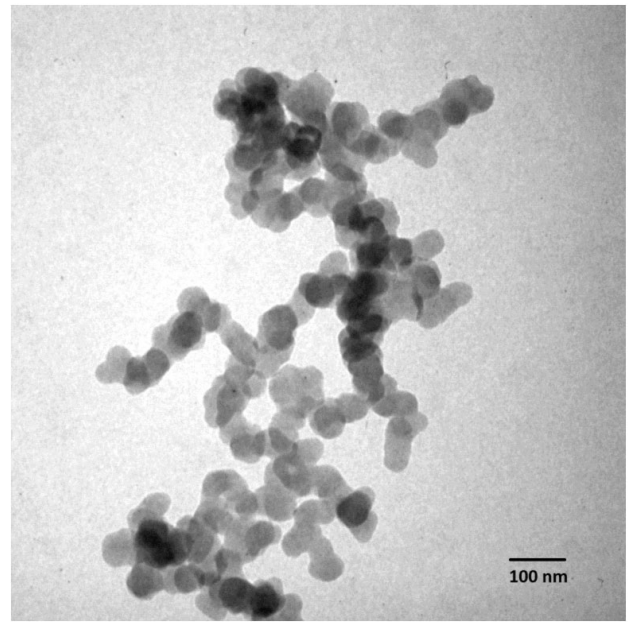

Fig. 2. TEM image of $\mathrm{CeO}_{2}$ nanocrystals.

Fig. 3a. Luminescence spectrum of $\mathrm{CeO}_{2}$ nanocrystals treated in oxidizing atmosphere consists of one band with maximum at $630 \mathrm{~nm}$, while spectrum of nonstoichiometric $\mathrm{CeO}_{2}$ nanocrystals consists of two bands with maxima at $390 \mathrm{~nm}$ and $630 \mathrm{~nm}$. As was shown previously, $630 \mathrm{~nm}$ band is determined by radiative relaxation in $\mathrm{Ce}^{4+}-\mathrm{O}^{2-}$ charge transfer state (CT-luminescence), $390 \mathrm{~nm}$ band is determined by $\mathrm{Ce}^{3+}$ ion luminescence and corresponds to electronic transition from excited $5 d^{1}$ state to the ground $4 f^{1}$ state of $\mathrm{Ce}^{3+}\left({ }^{2} F_{7 / 2}\right.$ and ${ }^{2} F_{5 / 2}$ terms) [12, 15].

Presence of shallow electronic traps usually modifies the processes of excitation relaxation at sub-band gap excitation. In $\mathrm{CeO}_{2}$ nanocrystals luminescence band at $390 \mathrm{~nm}$ originates from $5 d^{1}$ electronic state of $\mathrm{Ce}^{3+}$ ion, while $630 \mathrm{~nm}$ band - from

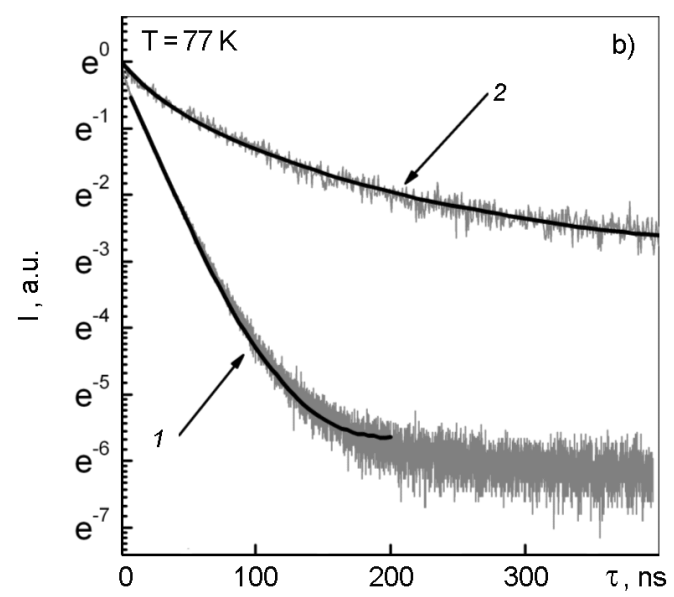

Fig. 3. a) Luminescence spectra of $\mathrm{CeO}_{2}$ nanocrystals treated in oxidizing atmosphere (1) and reducing atmosphere $(2), \lambda_{\text {exc }}=325 \mathrm{~nm} . T=77 \mathrm{~K}$. b) Decay curves of $\mathrm{CeO}_{2}$ nanocrystals treated in reducing atmosphere $\left(1-\lambda_{\text {reg }}=390 \mathrm{~nm} ; 2-\lambda_{\text {reg }}=630 \mathrm{~nm}\right), \lambda_{\text {exc }}=330 \mathrm{~nm}, T=77 \mathrm{~K}$. 

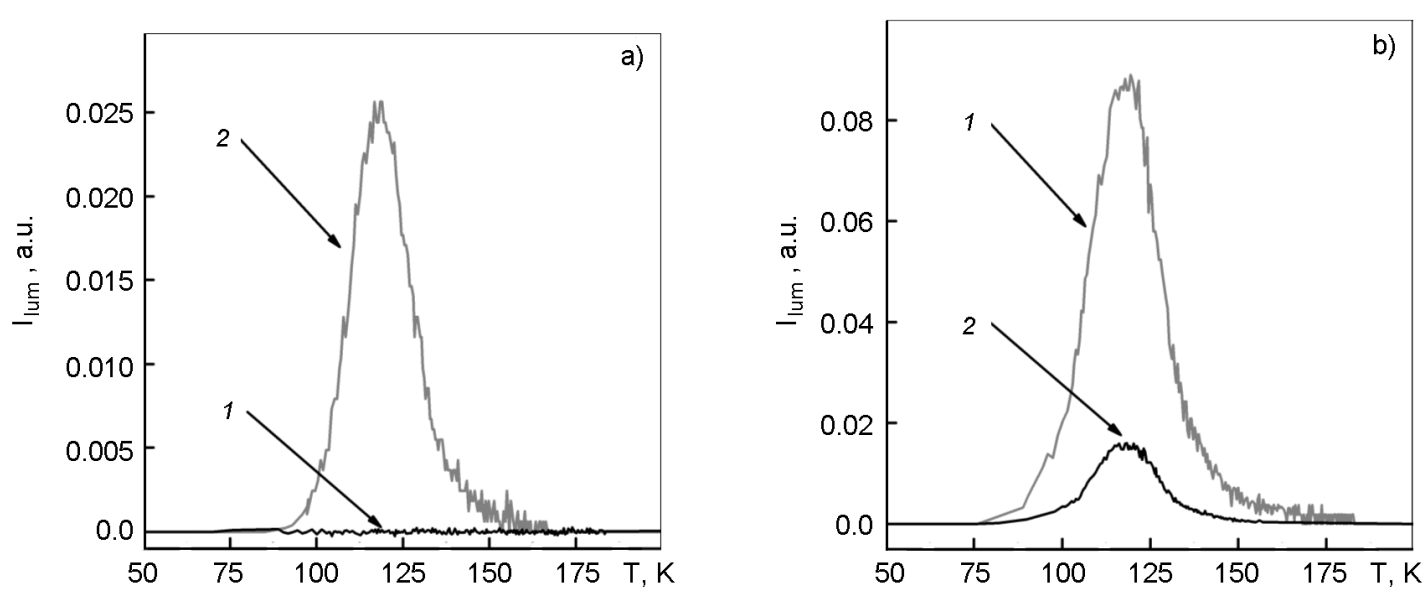

Fig. 4. a) TSL glow curve of $\mathrm{CeO}_{2}$ nanocrystals treated in reducing atmosphere $\left(1-\lambda_{\text {reg }}=390 \mathrm{~nm}\right.$, $2-630 \mathrm{~nm})$; b) TSL glow curve of $\mathrm{CeO}_{2}$ nanocrystals treated in reducing atmosphere (1) and in oxidizing atmosphere $(2)\left(\lambda_{\text {reg }}=630 \mathrm{~nm}\right)$.

relaxed $\mathrm{Ce}^{4+}-\mathrm{O}^{2-}$ charge transfer state located in the close vicinity to edges of empty $5 d^{0}$ and $4 f^{0}$ electronic bands, respectively. So an effective transport of electrons from luminescent centers to electron traps and vice versa can be predicted. So if the electronic traps are present near edges of either $5 d^{0}$ or $4 f^{0}$ electronic bands they must reveal itself in changing of excitation relaxation patterns and correspondent modification of luminescence decay curves can be expected.

The luminescence decay curves taken at 390 and $630 \mathrm{~nm}$ are shown in Fig. 3b. The decay curve of $390 \mathrm{~nm}$ emission band is monoexponential with decay time of $\tau \approx 25 \mathrm{~ns}$ that is typical for $5 d \rightarrow 4 f$ transitions of $\mathrm{Ce}^{3+}$ ions [16]. Monoexponential form of decay curve definitely demonstrates that either the electronic traps are absent near band edge of $5 d^{0}$ band or at least they are rather ineffective. Decay curve of $630 \mathrm{~nm}$ emission band has non-exponential pattern and can be approximated by hyperbolic law $I=I_{0} /(1+p t)^{\alpha}$ with $p=0.02$ and $\alpha=1.17$. Such type of luminescence decay curve is typical for decay in the presence of shallow traps. According to [17] $\alpha=1.17$ corresponds to about 30 acts of excitation re-trapping on the electronic traps during excitation lifetime.

To confirm the presence of shallow electrons traps thermally stimulated luminescence (TSL) glow curves of $\mathrm{CeO}_{2}$ nanoparticles with different stoichiometry were investigated. Each thermoluminescence peak corresponds to the release of an electron or hole from a particular trapping level during heating of the material [18]. The thermoluminescence was registered in the maximum of $\mathrm{Ce}^{3+} 5 d \rightarrow 4 f$ luminescence $(390 \mathrm{~nm})$ and in the maximum of $\mathrm{Ce}^{4+}-\mathrm{O}^{2-}$ luminescence $(630 \mathrm{~nm})$ after irradiation of the $\mathrm{CeO}_{2}$ nanocrystals with $\mathrm{He}-\mathrm{Cd}$ laser $\left(\lambda_{e x}=\right.$ $325 \mathrm{~nm}$ ).

Fig. 4 a shows the thermally stimulated luminescence glow curves between $50 \mathrm{~K}$ and $200 \mathrm{~K}$ for $\mathrm{CeO}_{2}$ nanocrystals treated in reducing atmosphere registered at 390 and $630 \mathrm{~nm}$. No peaks were observed in the TSL glow curve registered at $390 \mathrm{~nm}\left(\mathrm{Ce}^{3+}\right.$ band). This result agrees well with results obtained from decay curve and shows that there are no shallow electronic traps near $5 d^{0}$ band of ceria. TSL curve of $\mathrm{CeO}_{2}$ registered at $630 \mathrm{~nm}$ has one peak at $\sim 120 \mathrm{~K}(2)$. Presence of only one maximum in the curve indicates the presence of only one type of electron traps [18]. So, the $\mathrm{Ce}^{4+}-\mathrm{O}^{2-}$ charge transfer complexes are the recombination centers for de-trapped charge carriers and carriers escape thermally from the traps to the CT-band before their radiative recombination.

Thermoluminescence peak shape and methods of calculation of energy trap parameters are determined by the type of kinetics of recombination processes [18]. It is known [18, 19], the kinetics of thermoluminescence may be of the first or the second order due to different probability of charge carriers retrapping.

According to criteria of Randall and Wilkins [20] thermoluminescence kinetics of the first order is observed when the probability of re-trapping is negligible compared with the probability of recombination. So, first-order peak is asymmetric with most of the peak area being on the low temperature 

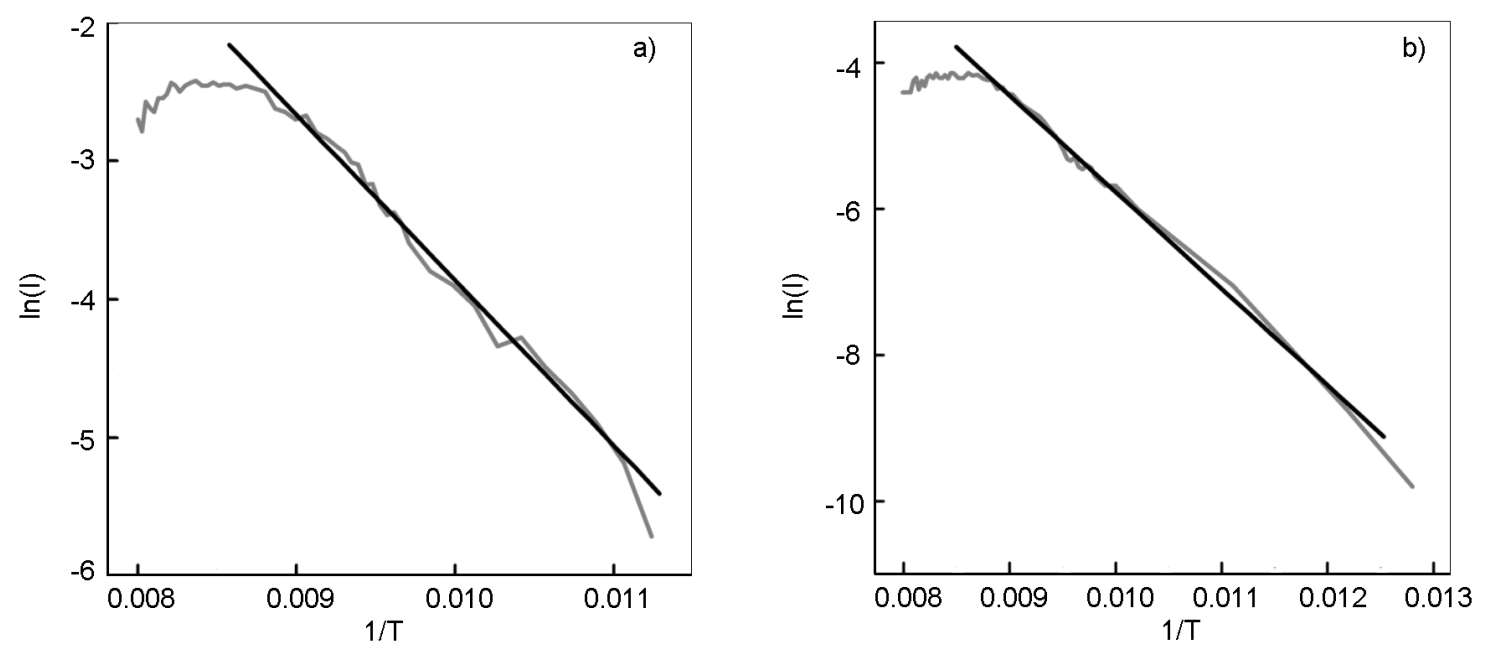

Fig. 5. TSL glow curves of $\mathrm{CeO}_{2}$ nanocrystals treated in reducing atmosphere (a) and in oxidizing atmosphere (b) in $\{1 / T, \ln (I)\}$ coordinates (slope of $120 \mathrm{~K}$ TSL peak is shown).

side from the maximum $\left(T_{m}\right)$. The secondorder glow curve is observed if the probability of re-trapping is high. Intensity of the second-order glow curve is more in the high temperature side of the peak [21]. Also the second-order TSL curve is more symmetrical than a first-order curve [18].

Fig. 4b shows the thermally stimulated luminescence glow curves between $50 \mathrm{~K}$ and $200 \mathrm{~K}$ for $\mathrm{CeO}_{2}$ nanocrystals treated in reducing and oxidizing atmosphere and registered at $630 \mathrm{~nm}$. Position of the maximum in the glow curves for $\mathrm{CeO}_{2}$ nanocrystals treated as in reducing, so in oxidizing atmosphere is located at $120 \mathrm{~K}$. This suggests the presence of traps of the same nature [18]. Increase of $120 \mathrm{~K}$ peak intensity with increase of oxygen deficiency indicates that this peak can be associated with oxygen defects. Both TSL glow are symmetrical, so in both cases second order kinetics of thermoluminescence is observed.

Knowledge of the order of thermoluminescence kinetics allows to determine an activation energy of electronic traps by the initial rise method. This method is known as the most accurate method for the secondorder kinetics [18, 22]. In the temperature range of $T<T_{m}$ TSL intensity is proportional to $\exp (-E / k T)$. This fact provides a simple mean for calculating the activation energy from the slope of $\ln (I)$ vs. $1 / T$ plot in the initial rise region [23]. The calculated values of activation energy for both $\mathrm{CeO}_{2}$ nanocrystals treated in reducing atmosphere and treated in oxidizing atmosphere are equal to $0.2 \mathrm{eV}$ (Fig. 5).
The same thermoluminescence kinetics, position of the maxima and activation energy confirms the suggestion about the same nature of electron traps for $\mathrm{CeO}_{2}$ nanocrystals treated in reducing and oxidizing atmosphere. Increase of TSL peak intensity with increase of oxygen deficiency indicates that this peak arises from oxygen vacancies. Activation energy of $0.2 \mathrm{eV}$ corresponds well with activation energy of $F^{+}$centers determined earlier from temperature dependence of correspondent luminescence band for $\mathrm{CeO}_{2}$ nanocrystals obtained by precipitation method [11]. So we can suppose that electronic traps for $\mathrm{CeO}_{2}$ investigated in our paper also are formed by $F^{+}$ ("oxygen vacancy + electron") centers.

\section{Conclusions}

Influence of shallow electron traps on the processes of $\mathrm{O} 2 p-\mathrm{Ce} 4 f$ excitation relaxation was shown by means of time-resolved spectroscopy and thermoluminescence analysis for $\mathrm{CeO}_{2}$ nanocrystals with different oxygen stoichiometry. It was shown that electron traps in $\mathrm{CeO}_{2}$ nanocrystals arise from oxygen vacancies and their impact depends strongly on the stoichiometry of nanocrystal. Activation energy of electronic traps calculated by means of the initial rise method for $\mathrm{CeO}_{2}$ nanocrystals was equal to about $0.2 \mathrm{eV}$ that corresponds well with position of levels of $F^{+}$centers relative to the bottom of $4 f^{0}$ band.

\section{References}

1. Z.Zhan, S.A.Barnett, Science, 308, 844 (2005). 
2. D.R.Ou, T.Mori, H.Togasaki et al., Langmuir, 27, 3859 (2011).

3. Z.C.Kang, Z.L.Wang, Adv.Mater., 15, 521 (2003).

4. H.Imagawa, A.Suda, K.Yamamura, S.Sun, J. Phys. Chem. C, 115, 1740 (2011).

5. R.W.Tarnuzzer, J.Colon, S.Patil, S.Seal, Nano Lett., 5, 2573 (2005).

6. E.-J.Park, J.Choi, Y.-K.Park, K.Park, Toxicology, 245, 90 (2008).

7. H.L.Tuller, A.S.Nowick, J. Electrochem. Soc., 126, 209 (1979)

8. P.Kofstad, A.Z.Hed, J. Amer. Cer. Soc., 50, 681 (1967).

9. A.Trovarelli, Catalysis by Ceria and Related Materials, World Scientific Publishing Company, New York (2002).

10. S.Mochizuki, F.Fujishiro, Phys.Stat.Sol.(b), 246, 2320 (2009).

11. S.Askrabic, Z.D.Dohcevic-Mitrovic, V.D.Araujo et al., J. Physics D:Appl. Phys., 46, 495306 (2013).

12. A.Masalov, O.Viagin, P.Maksimchuk et al., $J$. Luminescence, 145, 61 (2014).

13. X.Han, J.Lee, H.Yoo, Phys.Rev.B, 79, 10040310 (2009).
14. A.Serra, V.Severino, P.Calefi, S.Cicillini, $J$. Alloys Compd., 323-324, 667 (2001).

15. P.O.Maksimchuk, A.A.Masalov, Yu.V.Malyukin, J. Nano- and Electron. Phys., 5, 01004 (2013).

16. W.M.Yen, Sh.Shionoya, H.Yamamoto, Phosphor Handbook, 2d ed. CRC Press, Boca Raton (2007).

17. F.I.Adirovitch, J.Phys.Radium., 17, 705 (1956).

18. S.W.S.McKeever, Thermoluminescence of Solids, Cambridge University Press, London (1985).

19. R.Chen, Y.Kirsh, Analysis of Thermally Stimulated Processes, v.15, Pergamon Press, Oxford (1981).

20. J.T.Randall, M.H.F.Wilkins, Proc.R.Soc.London Ser.A, 184, 366 (1945).

21. G.E.J.Garlick, A.F.Gibson, Proc.Phys.Soc., 60, 574 (1948).

22. M.M.Elkholy, Mater. Chem. and Phys., 77, 321 (2002).

23. A.Halperin, A.A.Braner, Phys.Rev., 117, 408 (1960). 